economic development. He pointed out the need for co-ordinated interdisciplinary study of this and related subjects, and referred to a list of projects for new research which had been drawn up in collaboration with Professor G. Balandier and other members of the seminar. These suggested studies would be of three types: the study of motivations; the study of processes; the study of groups. A programme of researches on these lines should lead to a consideration of the whole range of problems created by industrial and economic development, and might be regarded as a first step towards the elaboration of a general theory of social change.

(A summary of the discussion at the Seminar with the full text of the list of tesearch projects has been prepared by Professor G. Balandier, who acted as rapporteur, and circulated in English and French by the International Research Office (International Social Sciences Council), ig Avenue d’Iéna, Paris.)

\title{
West African Institute of Social and Economic Research
}

THE West African Institute of Social and Economic Research held its third annual conference from 22 to 25 March, 1954. The conference was in two sections, the Sociology section at the University College, Ibadan, Nigeria, the Economics section at the University College, Achimota, Gold Coast.

Delegates to the Sociology section included: Monsieur B. Holas (Institut Français d'Afrique Noire, Centre Abidjan), Professor L. G. Cowan (School of International Affairs, Columbia University), Professor Lewis (Atlanta University, consultant sociologist to the Volta River Project Planning Commission), Dr. G. Jahoda and Mr. J. H. Nketia (Department of Sociology, University College of the Gold Coast), representatives of the Statistics, Education, and Social Welfate departments of the Nigerian Government, and of the C.M.S. and R.C.M. missions, members of the University College, Ibadan, and of W.A.I.S.E.R. The opening paper at the conference was given by Dr. K. O. Dike, the Deputy Director, on 'The Aims and Achievements of W.A.I.S.E.R.' Other papers presented dealt with the following subjects: The position of the Oba in modern Yoruba society (P. C. Lloyd, W.A.I.S.E.R.); the training of Local Government officers in Nigeria (I. A. Duncan, Nigerian Government); the family structure of Banyang Society (M. J. Ruel, W.A.I.S.E.R.); American interest in Africa (Professor L. G. Cowan); Bilingualism in Nigerian Society (Dr. L. F. Brosnahan, University College, Ibadan); the Egungun Society among the SouthWest Yoruba (P. Morton-Williams, W.A.I.S.E.R.); the role of the drummer in Akan Society (J. H. Nketia, University College, Gold Coast); Nigerian Social Medicine (Professor A. O. Ajose, University College, Ibadan); Benin religion (R. E. Bradbury, International African Institute); the population Census of Nigeria I9s 2-3 (J. Longden, Nigerian Department of Statistics); Social research in Nigeria x841-1950 (P. E. H. Hair, W.A.I.S.E.R.); Education and Nigerian national advance (A. Ogunsheye, University College, Ibadan); Inter-Tribal Unions in Kumasi (Dr. G. Jahoda, University College, Gold Coast).

The Economics section was under the direction of Professor J. W. Williams, Professor of Economics in the University College of the Gold Coast and representative of W.A.I.S.E.R. in the Gold Coast. Delegates included: members of the Economics Department of the University College, Gold Coast, representatives of the Gold Coast Government, of the Statistics and Marketing and Export Departments of the Nigetian Government, of Gold Coast missions, and members of W.A.I.S.E.R. Papers were presented as follows: Standards of living in the Gold Coast (W. B. Birmingham, Economics Department, U.C.G.C.); Labour Migration in the Northern Territories (R. B. Davison, Economics, U.C.G.C.); A Survey of an Ashanti Village (Mrs. R. Lawson); Industrial Relations in the Gold Coast (J. B. Heigham, Labour Department, Gold Coast); the Finance of Local Industry (Professor 
J. W. Williams); a Social Survey of Cape Coast Fishing (E. R. Rado, Economics, U.C.G.C.); Local Industries in the Northern Territories (L. M. Kubinski, Economics, U.C.G.C.); Problems of Expansion in the Gold Coast Fishing Industries (D. T. Gould, Fisheries Department, Gold Coast); The Muslim Association of the Gold Coast (J. H. Price, Economics, U.C.G.C.); a retrospect of the Nigerian Cocoa Survey (K. D. S. Baldwin, W.A.I.S.E.R.); the Textile trade in Accra (Miss G. Addae, Economics, U.C.G.C.).

Communicated by PhILIP Dark, Administrative Secretary

\section{Institut Francais d'Afrique Noire}

Le Rapport Annuel de r993 contient des aperçus des sections et des activités spécialisées d'IFAN, aussi que des rapports brefs des Centres Locaux, des missions du personnel de l'IFAN, listes des publications, des conférences et congtès organisés et des renseignements concernant des recherches achevées ou projetées.

La section de Sociologie a élaboté un programme de recherches dont les thèmes essentiels concernent: l'étude des problèmes posés par l'urbanisation et l'industrialisation au Sénégal (études dans les domaines économique, démographique et sociologique); l'étude plus générale de l'adaptation de la main-d'cuvre à la mécanisation (études de psychologie du travail). Dans ce programme sont compris des travaux collectifs aussi que des travaux exécutés séparément par des chercheurs individuels dans leurs domaines spécialisés.

Le plan de travail collectif prévoyait des recherches sur l'agglomération dakaroise (voir Africa, xxiii. 4, octobre 1953, pp. 355-6) dont plusieurs travaux ont été exécutés pendant l'année r953; une enquête générale par questionnaires portant sur les aspects essentiels de la vie individuelle, familiale, professionnelle (MM. Mercier, Hauser et Masse avec l'aide d'environ 80 enquêteurs bénévoles); enquête socio-démographique sur un secteur du quartier de Santyba, portant sur 200 familles environ; enquête sur les associations de type nouveau, en particulier les syndicats et les associations culturelles (M. Mercier); enquête dans les industries de transformation de la région Dakar-Rufisque (M. Hauser); études économiques - stage préparatoire (M. Mersadier). En outre MM. Mercier et Masse ont participé à une enquête collective sur Thiès - centre urbain du Sénégal. Le recensement de la ville de Thiès, exécuté sous les auspices de la Statistique Générale, aussi qu'un plan sommaire de la ville établi avec l'aide des photographies aériennes ont fourni des bases de travail qui permettaient d'envisager à Thiès un travail plus systématique que celui de Dakar. Un stage de formation et de sélection des enquêteurs africains qui devaient participer à l'enquête a été organisé à l'IFAN.

Aux centres locaux d'IFAN, M. B. Holas (Côte d'Ivoire) poursuit, parallèlement à d'autres travaux de longue haleine, ses études de sociologie religieuse chez les Sénoufo du nord de la Côte d'Ivoire, et en particulier sur les changements récents intervenus dans la structure du système initiatique tribal.

Le Dr. Köbben (Côte d'Ivoire) poursuit une étude sur l'évolution des coutumes et de la vie sociale de différents villages indigènes en présence et en fonction de l'évolution économique et politique de la Côte d'Ivoire.

M. Le Moal (Haute-Volta) a poursuivi ses recherches sur la société Bobo-Fing, et, par ailleurs, a commencé des recherches de sociologie pratique sur le problème des migrations de main-d'œuvre sous l'angle des conséquences sociales et des changements culturels, en particulier chez les Mossi.

\section{Growth of East Africa's First Museum: Memorial to a Kenya Governor}

Just over 40 years ago, 72 enthusiasts, members of the recently formed Natural History Society of Kenya, attended a meeting to discuss the possibility of creating Nairobi's first 